\title{
ANALISA METODE MEDIAN PADA PENENTUAN TITIK TENGAH DI GOOGLE MAPS
}

\author{
Kurnia Rizki Novianto, Sumarsono'1), Yuliani Indrianingsih'2) \\ 1 Teknik Informatika Universitas Islam Negeri Sunan Kalijaga Yogyakarta \\ 2Jurusan Teknik Informatika Sekolah Tinggi Teknologi Adisutjipto Yogyakarta \\ informatika@stta.ac.id
}

\begin{abstract}
Information technology to used facilitate the lives of humans in performing activities have come to the stage of the hand grip. The intent of this grip is a form of computer that is small and can be hand held adult human hand, for example in the form of smartphones, laptops, and tablets. This equipment can help people to access the internets that provide maps and location services on earth. With the internet user will easily dig resources with ease. Thus with the internet it is essential for human life until the source of the future. Problems that arise in the world of internet or computer network often arise and prevent the problem. Limitations of resources based on google maps are very necessary for a person to get the intended location. This system will help a person in getting the distance of the intersection to a point latitude and longitude coordinates by calculating the midpoint of the user, and then calculate the distance between the midpoint of the location suggested by the system so that the user gets close location to conduct meetings. To specify the system location data using Google Place API to obtain complete data locations along the coordinates of latitude and longitude of a location.
\end{abstract}

Keyword: median method, Geolocation, Google Place API, Geometry Place API, Geocoder API.

\section{Pendahuluan}

Teknologi informasi yang digunakan manusia untuk mempermudah kehidupan dalam menjalankan aktifitas sudah sampai pada tahapan genggaman tangan. Maksud dari genggaman tangan ini yaitu bentuk komputer yang kecil dan dapat digenggam tangan manusia dewasa, antara lain dalam bentuk smartphone, Laptop, dan Tablet. Peralatan ini dapat membantu manusia untuk mengakses jaringan internet yang memberikan layanan peta dan lokasi dibumi.Hal inilah yang memunculkan ide untuk menganalisa titik tengah suatu koordinat dengan menggunakan metode median sebagai acuannya. Metode median merupakan metode yang saya gunakan untuk menetukan hasil titik tengah dalam penentuan posisi titik pengguna satu dengan pengguna yang lain berbasis titik koordinat latitude dan longitude. Untuk menghitung titik temu antara penggguna berdasarkan lokasi pengguna dengan basis titik koordinat latitude dan longitudedengan menggunakan metode median. Proses ini dilalui dengan beberapa tahap yang meliputi, harus mengetahui titik koordinat latitude dan longitude pengguna satu dengan yang lain, kemudian dilakukan proses perhitungan dengan memanfaatkan rumus $a, b, c$ atau phytagorasuntuk menentukan titik temu tersebut.

Pencarian titik temu dalam peta digital dihitung dengan memanfaatkan metode median untuk menghasilkan titik koordinat latitude dan longitude yang menujuk pada sebuah lokasi.Lokasi ini dapat berupa ruang terbuka ataupun ruang tertutup, jika ruang terbuka 
maka tidak layak digunakan untuk pertemuan, sehingga perlu direkomendasikan keruang tertutup didekat titik koordinat tersebut. Latitude dan longitude dapat ditemukan pada peta, baik peta analog mapun peta digital. Latitude dan longitude dibuat berdasarkan sumbu bumi horizontal dan vertikal, atau bujur dan lintang. Garis lintang itu sendiri adalah garis yang melingkari bumi, dari equator hingga kebagian kutub utara dan kutub selatan bumi dan garis bujur ini bisa dikatakan garis maya yang ditarik dari kutub selatan atau sebaliknya. Pembagian ini berdampak pada lokasi dibumi secara nyata, jika diperlukan dalam pencarian titik suatu koordinat untuk mencari lokasi atau tempat.

\section{Metodologi}

\subsection{Tinjauan Pustaka}

Algoritma jawa (Jarak dan Waktu) merupakan suatu metode jurnal dari Khairur Razikin pada tahun 2012 yang bertujuan untuk menemukan solusi dasar menentukan jarak antara dua buah komputer melalui jaringan wirelessLAN (LocalAreaNetwork)/hostspot dan memudahkan dalam pencarian jarak antara dua buah komputer. Rumus yang digunakan untuk menentukan jarak tersebut dengan rumus pythagoras yang telah dimodifikasi yaitu $Z_{\text {baru }}=\frac{Z}{2}$ dengan keterangan $Z$ adalah hasil dari teorema pythagoras, nilai 2 adalah konstanta untuk sudut $40^{\circ}$ pada segitiga sama kaki, dan $Z_{\text {baru }}$ adalah hasil modifikasi rumus pythagoras. Hasil pengujian aplikasi algoritma jawa ini didapatkan hasil sebuah tabel jarak antara dua buah komputer dalam jaringan wireless LAN/hostspot untuk masing-masing titik atau jarak.

\subsection{Teori Median}

Median adalah ukuran pemusatan dimana data tersebut terbagi menjadi dua sama banyak. Median dinotasikan dengan M. Untuk data yang belum dikelompokkan, tentunya data ini harus diurutkan terlebih dahulu dari data yang terkecil hingga data yang terbesar. Median data ditentukan dengan notasi seperti rumus di bawah ini :

$$
\begin{aligned}
& M=\frac{X_{\left(\frac{n}{2}\right)}+X_{\left(\frac{n}{2}+1\right)}}{2}(\text { jika n genap) } \\
& M=X_{\left(\frac{n+1}{2}\right)}(\text { jika n ganjil) }
\end{aligned}
$$

\subsection{Pengertian Algoritma}

Algoritma merupakan susunan yang logis dan sistematis untuk memecahkan suatu masalah atau untuk mencapai tujuan tertentu. Dalam dunia komputer, Algoritma sangat berperan penting dalam pembangunan suatu software. Dalam dunia komputasi, contoh penggunaan Algoritma adalah dalam pembuatan program pada bahasa pemrograman seperti bahasa $C$, Delphi, Visual Basic dan sebagainya. Dengan syntax pada tiap bahasa pemrograman dan Algoritma, maka akan tersusun program-program dan terlahirlah software.

\subsection{Api Google Place}

Api Google places merupakan layanan yang diberikan dari google yang memberikan informasi tentang tempat-tempat sesuai dengan posisi (Latitude, Longitude) yang telah ditentukan. Untuk menggunakan Api Google Place pengguna harus terlebih dahulu 
mempunyai akun google, sehingga pengguna bisa menggunakan layanan Api Google Place tersebut dan melakukan hak akses terhadap google tersebut.

\subsection{Perancangan Algoritma}

Algoritma yang baik haruslah melewati proses pengujian terlebih dahulu, sehingga dapat diketahui performance dari suatu algoritma. Metode median telah melewati beberapa pengujian dengan cara melakukan perhitungan peserta pertemuan sebanyak mungkin. Pengujian metode median juga bertujuan untuk mengetahui kekurangan metode median ini.Terdapat beberapa peserta dititik koordinat yang berbeda yang akan dihitung dan diuji keakuratannya, misalnya :

* Ada tiga buah titik koordinat yang terletak didaerah yang berbeda dan mereka akan melakukan pertemuan dengan cara menentukan jarak titik temu mereka dengan menghitung titik tengah mereka?

Titik koordinat A berada di Jl. Janti dengan titik koordinat (-7.79858, 110.40774), titik koordinat B berada di Sekolah Tinggi Teknologi Adisutjipto dengan titik koordinat (7.79841, 110.41722), dan titik koordinat C berada di SDN Ngentak dengan titik koordinat $(-7.80670,110.41906)$.

$$
\text { Titik tengah }=\frac{\sum \mathrm{x}, \Sigma \mathrm{y}}{\mathrm{n}}
$$

$$
\text { Titik tengah }=\frac{\begin{array}{c}
x(-7.79858 \pm 7.79841 \pm 7.80670), \\
3
\end{array}}{\text { (110.40774+110.41722+110.41906) }}
$$

$$
\text { Titik tengah }=\frac{(-23.40369),(331.24402)}{3}
$$

$$
\text { Titik tengah }=-7.80123,110.41467
$$

Dari hasil perhitungan titik tengah dari ketiga user diatas dengan titik koordinat latitude -7.80123 latitude 110.41467. Dimana titik tersebut telah diketahui beberapa hasil titik tengah ketiga titik koordinat tersebut, sehingga peserta tidak saling merugikan satu sama lain.

\section{Hasil dan Pembahasan}

Pada tampilan gambar 1 menunjukkan dimana User harus melakukan login terlebih dahulu, dengan cara User harus memasukkan email dan password yang sudah dibuat dipendaftaran User. Setelah masuk maka User bisa mengeksekusi aplikasi. 


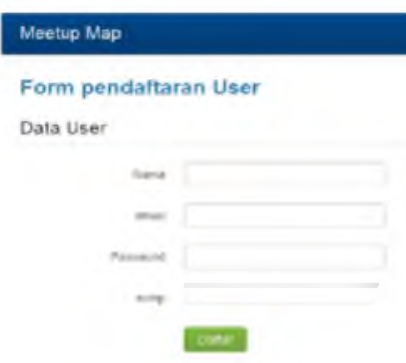

Gambar 1. Tampilan utama aplikasi meetup

Pada tampilan gambar2 menunjukkan dimana User harus melakukan login terlebih dahulu, dengan cara User harus memasukkan email dan password yang sudah dibuat dipendaftaran User. Setelah masuk maka User bisa mengeksekusi aplikasi.

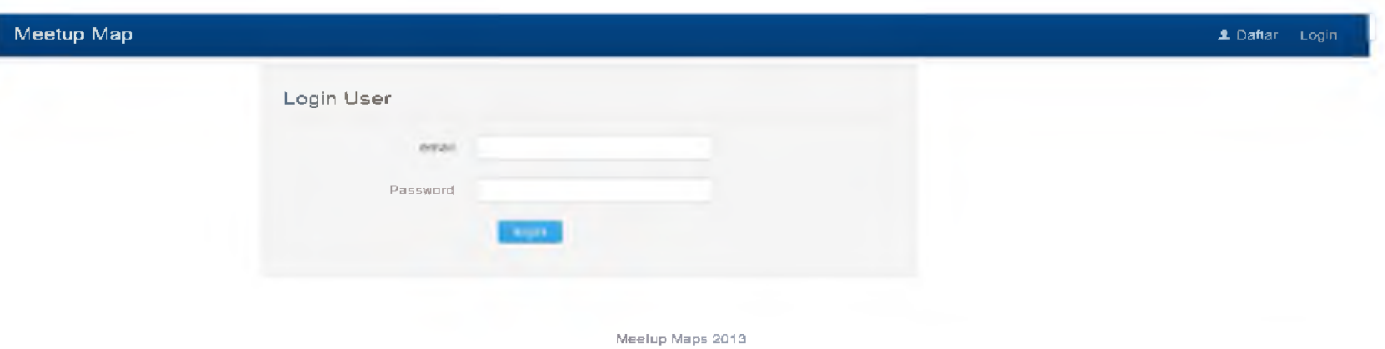

Gambar 2. Tampilan Login

Pada tampilan tambah meetup ini User diminta untuk memasukkan nama rencana kegiatan untuk peserta yang akan diundang dengan ketentuan User harus memasukkan nama meetup, tanggal meetup, dan jam berapa sehingga kegiatannya jelas dan nama kegiatannya apa.Seperti gambar 3 dibawah ini.

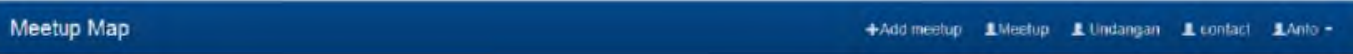

tambah meetup

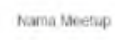

tangal ueetup

Jam Weethp

Meetup Maps 2013

Gambar 3. Tampilan tambah meetup 
Pada tampilan tambah meetup ini User diminta untuk memasukkan nama rencana kegiatan untuk peserta yang akan diundang dengan ketentuan User harus memasukkan nama meetup, tanggal meetup, dan jam berapa sehingga kegiatannya jelas dan nama kegiatannya apa.Seperti gambar 4 di bawah ini.

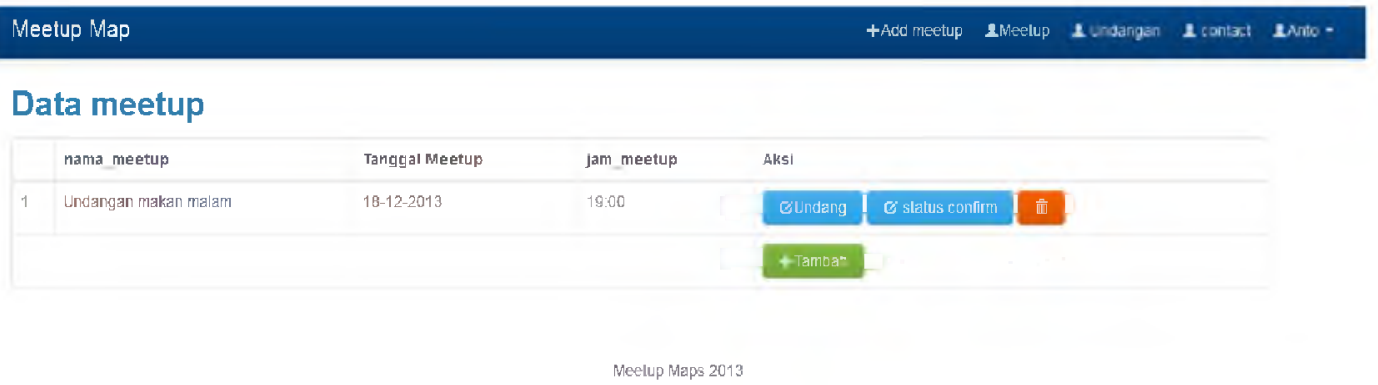

Gambar 4. Tampilan Tambah undangan meetup

Tampilan lokasi User pada aplikasi ini berfungsi sebagai pemberitahuan lokasi User yang diundang. Secara otomatis sistem akan mendapatkan titik koordinat User berupa Latitude dan LongitudeUser tersebut. Seperti gamabar 5 dibawah ini.

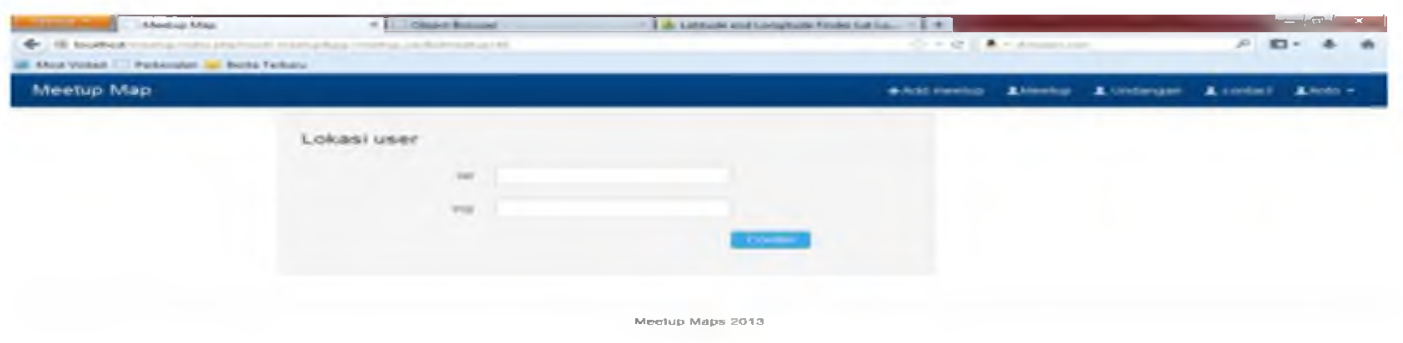

Gambar 5. Tampilan lokasi User

Pada tampilan data meetup lokasi, tampilan ini berfungsi sebagai data peserta yang sudah melakukan konfirmasi melalui email dan sudah mengirim lokasi mereka berbasis titik koordinat Latitude dan Longitude yang kemudian sistem akan melakukan perhitungan titik tengah dengan cara mengklik tombol hitung titik tengah. Sistem akan secara otomatis menghitung titik tengah antara peserta tersebut. Seperti gambar 6 dibawah ini.

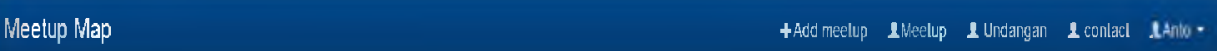

\begin{tabular}{|c|c|c|c|c|}
\hline & User & status & Iatitude & Longitude \\
\hline 1 & punamasarnputisi1@grmal cor & YES & 7822089 & 110.376817 \\
\hline 2 & deuicaturap ka@g̣mai .cum & YES & -7.826182 & $" 10.367333$ \\
\hline 3 & nizbernlo91@gmai.com & YES & -7.7973873 & $" 10.4069554$ \\
\hline
\end{tabular}

Gambar 6. Tampilan Data meetup konfirmasi 
Pada tampilan dialog box, tampilan ini berfungsi sebagai tombol penghapus. Ketika User mengklik tombol hapus, maka daftar rencana kegiatan yang dibuat pengundang akan terhapus dan tidak bisa tampil sebagai history.

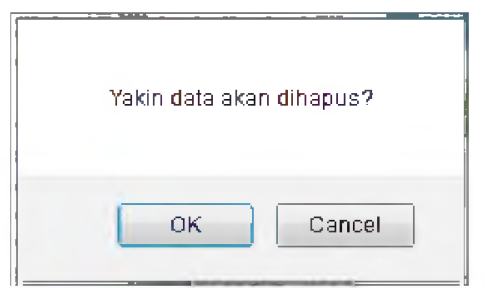

Gambar 7. Tampilan dialog box button hapus

Pada tampilan hasil titik tengah berfungsi sebagai penunjuk arah dimana titik tengah telah ditemukan lengkap beserta titik koordinat Latitude dan Longitude yang sudah dikonversi menjadi nama area di lokasi titik tengah yang telah ditemukan. Titik tengah tersebut ditandai dengan marker diatas dan digambarkan dengan garis yang mengelilingi lokasi peserta tersebut. Seperti gambar 8 di bawah ini.

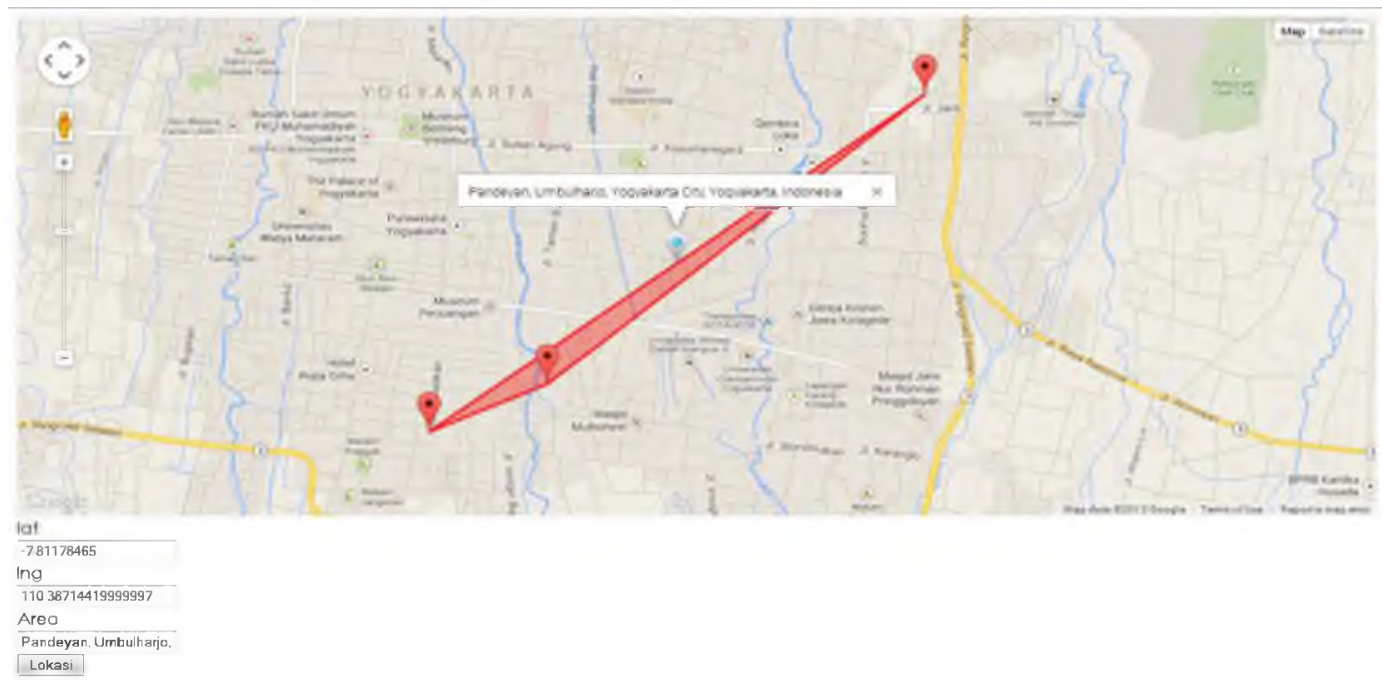

Gambar 8. Tampilan hasil titik tengah

Pada tampilan lokasi yang disarankan, tampilan ini berfungsi untuk mendapatkan lokasi strategis disekitar area titik tengah lengkap beserta nama lokasi, alamat lokasi, dan jarak lokasi dengan titik tengah sehingga User dengan mudah mencerna dimana sistem akan menyarankan User tersebut untuk menghadiri pertemuan. Kemudian sistem jarak juga akan tersimpan kedalam database dengan mengklik tombol simpan. Seperti gambar 9 dibawah ini.

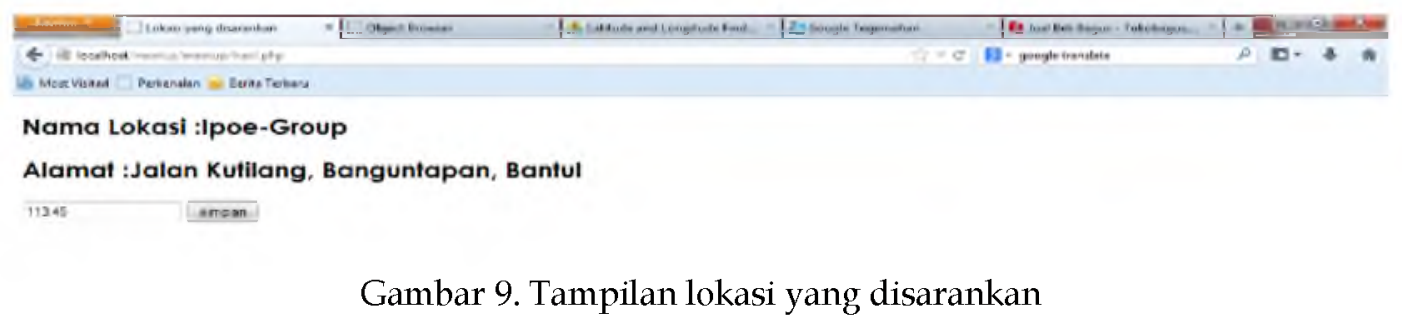


Tampilan kembali ke halaman awal ini berfungsi sebagai apabila jarak berhasil disimpan ke dalam database, dan jika diklik tombol back to home maka akan berpindah ke halaman utama atau halaman index dari sistem ini. Seperti gambar 10 dibawah ini.

arak berhasil dinitung dan dimasukan kedalam database back to home

Gambar 10. Tampilan kembali ke halaman awal

Pada tampilan data meetup ini berfungsi sebagai history data kegiatan yang dimasukkan oleh pengundang dan data-data yang dimasukkan meliputi nama kegiatan, tanggal kegiatan, jam kegiatan, dan status kedatangan. Selain itu ada tombol lokasi yang bertujuan untuk mengarahkan lebih jelas dimana lokasi pertemuan oleh pengundang dan juga peserta yang diundang.Seperti yang ditunjukkan gambar 11 dibawah ini.

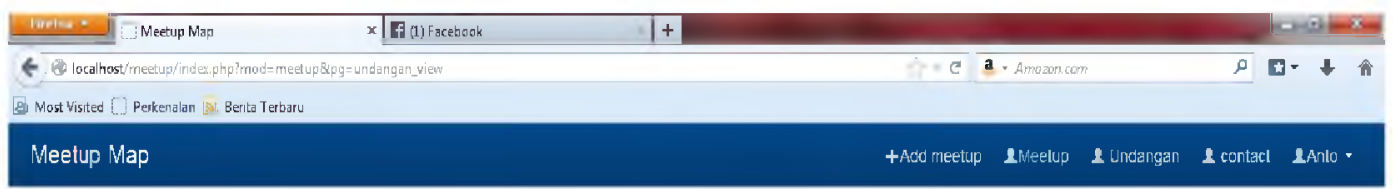

Data meetup

\begin{tabular}{|c|c|c|c|c|c|}
\hline & Hama méetup & Tanggal Meetup & Jam meetup & Status kec atangam & Lokasi \\
\hline 1 & Undangan makan malam & 18-12-2013 & 19:00 & YES & Lokas \\
\hline
\end{tabular}

Gambar 11. Tampilan data meetup

Pada tampilan lokasi pertemuan ini berfungsi sebagai penunjuk dimana lokasi yang disarankan lengkap dengan nama tempat, nama lokasi, area lokasi, jarak antara titik tengah dengan lokasi, Latitude, dan Longitude titik tengah. Selanjutnya ada button direction yang berfungsi sebagai penunjuk arah dari User berdiri ke lokasi yang disarankan tersebut.Seperti gambar 12 dibawah ini. 


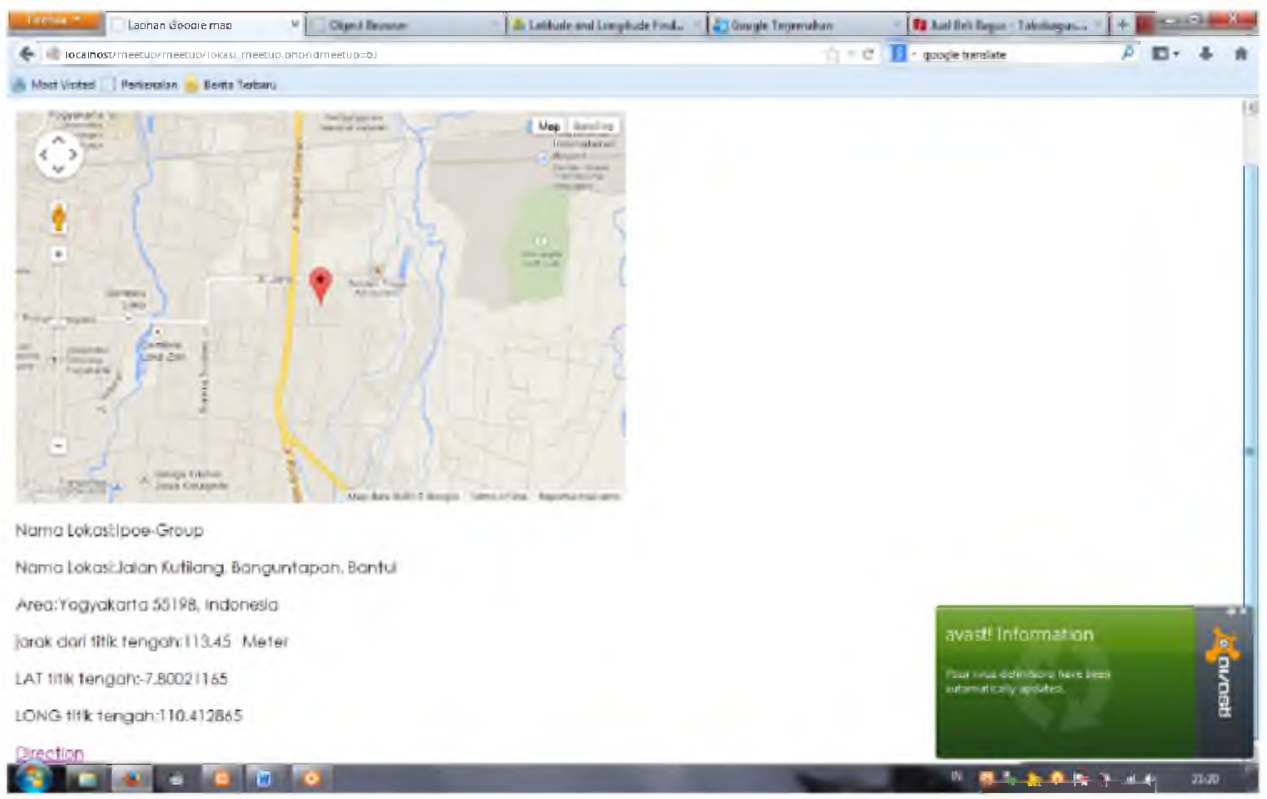

Gambar 12. Tampilan lokasi pertemuan

Tampilan penunjuk arah ini berfungsi sebagai penunjuk arah kepada User pertama kali berdiri sampai ke lokasi yang disarankan sistem, sehingga User dengan mudah mengetahui jalan dimana lokasi pertemuan tersebut dengan cara mengklik tombol confirm, sebelum sistem menunjukkan peta penunjuk arah dengan peta digital. Seperti gambar 13 dibawah ini.

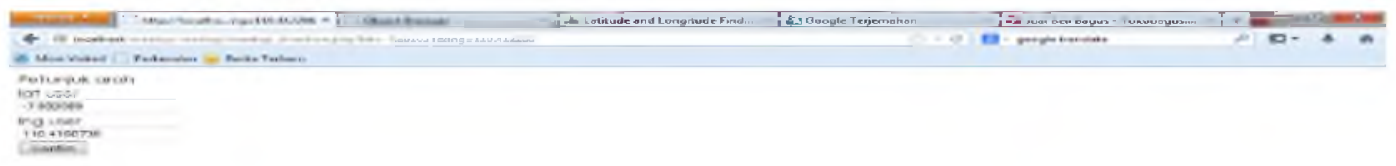

Gambar 13. Tampilan penunjuk arah

Tampilan peta penunjuk arah ini berfungsi sebagai penunjuk arah dari lokasi kita berdiri terhadap tujuan lokasi yang disarankan oleh sistem, yang digambarkan dengan jelas rute mana yang terdekat untuk menuju lokasi tersebut.Seperti gambar 14 dibawah ini.

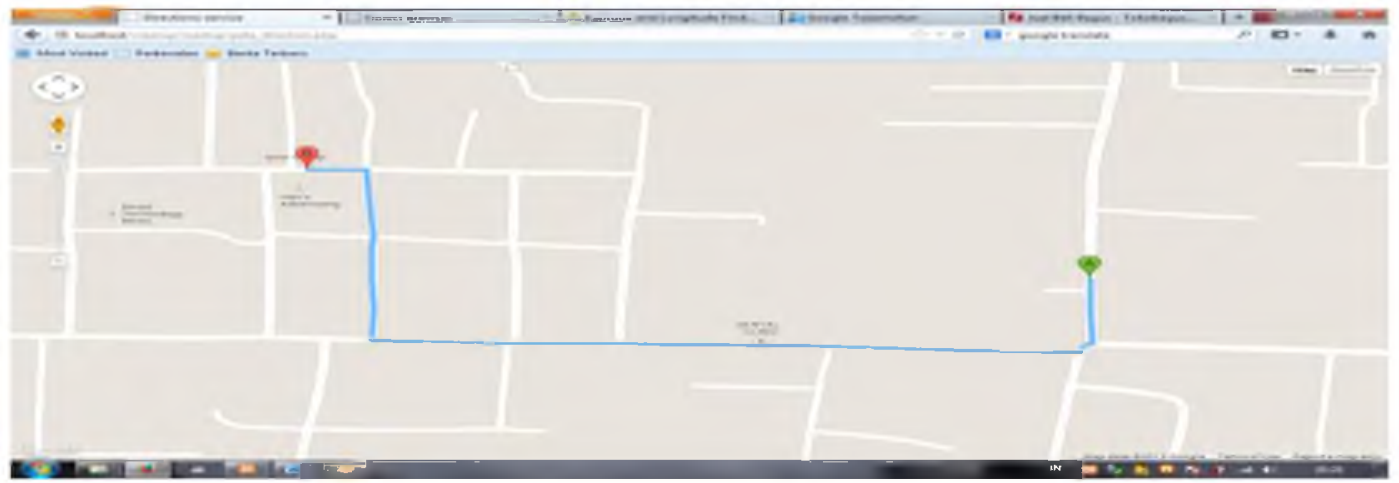

Gambar 4.14. Tampilan peta penunjuk arah 
Tampilan data User ini berfungsi sebagai record data-data User yang sudah mendaftar yang kemudian dirangkum menjadi satu dalam daftar User, dan User yang bersangkutan juga bisa melihat kontak nomer telepon untuk menghubungi User yang bersangkutan. Seperti gambar 15 dibawah ini.
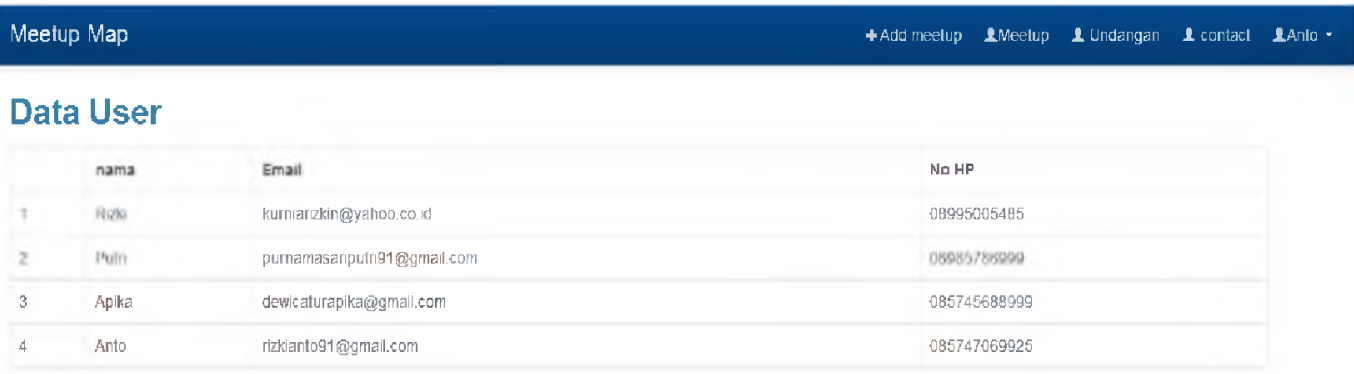

Gambar 15. Tampilan data User

Tampilan ganti password ini berfungsi sebagai pergantian password User dalam hal keamanan User, ketika ada User yang mengetahui password kita.Maka User bisa mengganti passwordnya dengan hal keamanan password, sehingga tidak terjadi penyalahgunaan dalam penggunaan sistem ini.Seperti gambar 16 dibawah ini.

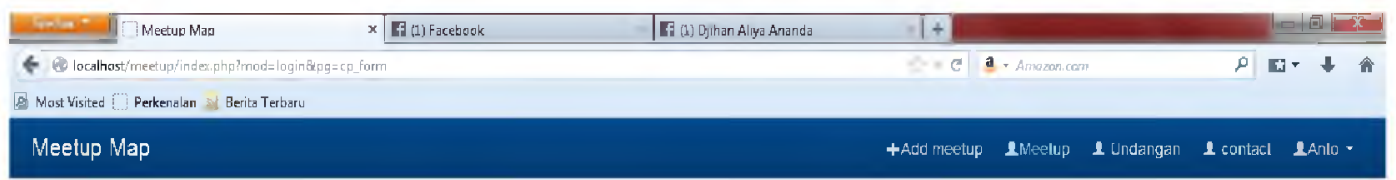

Ganti Password

Gambar 16. Tampilan ganti password

Pada pengujian ketepatan untuk mengetahui perbandingan perhitungan manual dan sistem dengan penjabaran tabel 1 dibawah ini.

Tabel 1 Hasil Analisa Uii Ketepatan

\begin{tabular}{|l|l|l|l|l|l|l|}
\hline \multirow{2}{*}{ No } & \multirow{2}{*}{$\begin{array}{l}\text { Usmlah } \\
\end{array}$} & \multicolumn{2}{|l|}{ Hasil Sistem } & \multicolumn{2}{l|}{ Hasil Manual } & Hasil \\
\cline { 2 - 7 } & Latitude & Longitude & Latitude & Longitude & Analisa \\
\hline 1 & 2 User & -6.923423 & 107.617424 & -6.923423 & 107.617424 & Sama \\
\hline 2 & 3 User & -6.913539 & 107.617424 & -6.922614 & 107.618262 & Berbeda \\
\hline 3 & 4 User & -6.913539 & 107.622252 & -6.918013 & 107.630149 & Berbeda \\
\hline 4 & 5 User & -6.9212825 & 107.625492 & -6.922614 & 107.630149 & Berbeda \\
\hline 5 & 6 User & -6.921282 & 107.631844 & -6.920047 & 107.634977 & Berbeda \\
\hline 6 & 7 User & -6.921282 & 107.657475 & -6.922614 & 107.639805 & Berbeda \\
\hline 7 & 8 User & -6.921282 & 107.657475 & -6.923423 & 107.643045 & Berbeda \\
\hline 8 & 9 User & -6.932859 & 107.657475 & -6.922614 & 107.643281 & Berbeda \\
\hline 9 & 10 User & -6.932859 & 107.657475 & -6.923423 & 107.644053 & Berbeda \\
\hline
\end{tabular}


Dari hasil analisa uji ketepatan antara hasil yang diperoleh oleh sistem dengan hasil perhitungan yang diperoleh secara manual yaitu terdapat kesamaan apabila hanya terdapat 2 user dan perbedaanakan terjadi apabila terdapat lebih dari 2 user. Perbedaan antara perhitungan manual dengan aplikasi tidak terlalu besar selisih angkanya.Hal ini disebabkan pada aplikasi hasil perhitungan merujuk pada tempat yang sudah ditandai di aplikasi google maps.

\section{Kesimpulan dan Saran}

Setelah melakukan pengujian terhadap aplikasi hasil rancangan, maka dapat diambil kesimpulan :

1. Metode mediantidak dapat diterapkan dalam pengimplementasian sistem untuk mencari nilai titik tengah dan menentukan lokasi yang disarankan.

2. Penggunaan aplikasi ini membantu pengguna untuk melakukan pertemuan jarak terdekat antar pengguna, sehingga tidak saling merugikan antara pengguna satu dengan yang lain.

3. Semakin banyak pengguna yang akan diundang dan semakin lama pula waktu proses sistem dalam mengeksekusi.

4. Terdapat kesamaan hasil uji ketepatan apabila hanya terdapat 2 user dan perbedaan akan terjadi apabila terdapat lebih dari 2 user.

Sedangkan saran yang dapat digunakan untuk pengembangan selanjutnya adalah :

1. Aplikasi yang dihasilkan dapat mencapai waktu yang lebih cepat dan lebih akurat dalam penentuan titik tengah pada sistem tersebut.

2. Aplikasi dikembangkan dengan berbasis android, sehingga bisa diakses via smartphone dan perangkat lainnya.

\section{Daftar Pustaka}

Eichorn, Joshua, 2006, Understanding Ajax: Using Javascript to Create Rich Internet Application, Prentice Hall. Crawfordsville.

Foister, Klaus dan Oggl, Bernd, 2011, HTM5 Guidelines for Web Developer, Pearson, Crawfords.

Nugroho, Sigit, 2008, Dasar-dasar Metode Statistika, Jakarta, PT. Grasindo (Gramedia Widiasarana Indonesia).

Razikin, Khairur, 2012, Algoritma Jawa (Jarak dan Waktu), Compiler Volume 1, Yogyakarta.

Raharjo, Budi, 2011, Belajar otodidak PEMROGRAMAN WEB dengan PHP + ORACLE, Bandung, Informatika Bandung.

Ramadijanti, Nana, 2008,Aplikasi WEB Dasar Pemrograman PHP,Surabaya, Politeknik Elektronika Negeri Surabaya.

Samsyiar, Evara, 2006, Administrasi Database System 10g, Jakarta, PT. Elex Media Komputindo. 